\title{
PENDIDIKAN SEKS MELALUI MEDIA LAGU DI KELOMPOK BERMAIN SITI KHADIJA DESA PAKULI KECAMATAN GUMBASA KABUPATEN SIGI
}

\author{
Faozia I Lamadjido ${ }^{1)}$ Rusdin $^{2)}$ Kasmiati $^{3)}$ \\ ${ }^{1}$ Mahasiswa Program Studi PIAUD FTIK Institut Agama Islam Negeri Palu \\ ${ }^{2}$ Dosen Fakultas Tarbiyah dan Ilmu Keguruan Institut Agama Islam Negeri Palu \\ ${ }^{3}$ Dosen Fakultas Tarbiyah dan Ilmu Keguruan Institut Agama Islam Negeri Palu
}

\begin{abstract}
ABSTRAK
Penelitian ini membahas tentang Pendidikan Seks melalui Media Lagu di Kelompok Bermain Siti Khadija Desa Pakuli Kecamatan Gumbasa Kabupaten Sigi. Penelitian ini menggunakan pendekatan kualitatif. Teknik pengumpulan data melalui observasi, wawancara dan dokumentasi. Teknik analisis data yang digunakan adalah reduksi data, penyajian data dan verifikasi data. Berdasarkan hasil penelitian, diperoleh bahwa pelaksanaan pendidikan seks di lakukan dengan mengajarkan anak pendidikan seks pada anak berusia 3-4 tahun, Sekolah telah merancang pendidikan seks yang efektif dalam pemberian pembelajaran ke peserta didik, mengunakan metode bercerita dan Tanya jawab antara guru dan siswa serta mengunakan media lagu sekolah juga mengunakan tema diriku dalam pembahsan full tentang pendidikan seks. Keberhasilan pendidikan seks di Kelompok Bermain siti khadija sendiri terlihat ketika sekolah berinisiatif membuat diskusi bersama guru-guru untuk membahas tentang pentingnya pembelajaran seks, dan pengunaan media lagu sentuhan boleh dan sentuhan tidak boleh sebagai lagu wajib dinyanyikan peserta didik sebelum pulang sekolah, pengunaan lagu juga dikombinasikan dengan 6 aspek perkembangan yaitu, nilai agama dan moral, bahasa, kognitif, motorik kasar dan halus, sosial-emosional, dan seni.
\end{abstract}

Kata Kunci : Pendidikan Seks, Media Lagu

\section{PENDAHULUAN}

Pendidikan seksual sekarang ini sangatlah penting karena dengan banyaknya kasus-kasus kekerasan seksual terhadap anak yang terjadi di Indonesia dalam hal ini keluarga dan lingkungan sekitar perlu berkerja sama dalam melindungi anak, terlebih lagi Melindungi anak didasari dengan pikiran bahwa anak adalah makhluk lemah yang tidak mampu mencegah atau melawan berbagai ancaman disekitarnya, sehingga ia mulai terluka fisik maupun mentalnya. karena konstruksi tubuh anak yang kecil dan ketidakmampuannya atau belum mampunya anak untuk mempertimbangkan 
resiko bahaya yang mungkin terjadi pada dirinya, baik karena tindakan pribadinya sendiri maupun bahaya laten yang ada di lingkungan sekitarnya.

Perlindungan masalah kekerasan seksual sudah sepatutnya diberikan kepada anak sejak dini. Pendidikan tersebut tentu harus disesuaikan dengan usia anak. Tujuan penelitian tersebut memberikan penjelasan terhadap anak tentang perbedaan anatar perempuan dan laki-laki,mengenai anatomi dari tubuhnya dan cara melindungi dirinya. dengan materi dan cara penyampaian yang benar pendidikan seksual nantinya akan membentengi anak dari hal-hal yang tidak di inginkan.

Dalam Undang-Undang Negara telah menjelaskan Anak sebagai generasi penerus cita-cita dan masa depan suatu bangsa oleh karena itu untuk mempersiapkan pewaris bangsa yang berkualitas dan sejahtera. Sesuai pasal 1 ayat 2 Dari UndangUndang Republik Indonesia Nomor 35 Tahun 2014 Tentang Perubahan Atas Undang-Undang Perlindungan Anak Negara berkewajiban untuk:

“...menjamin dan melindungi Anak dan hak-haknya agar dapat hidup tumbuh, berkembang, dan berprestasi secara optimal sesuai dengan harkat dan martabat kemanusian, serta mendapatkan perlindungan dari diskriminasi."

Sedangkan Badan Pusat Stastistika pada tahun 2019 memperkirakan penduduk Indonesia mencapai jumlah total 266.910.000 jiwa dan data tersebut 66.170.000 jiwa merupakan anak-anak (0-14 tahun), ${ }^{2}$ dengan puluhan juta jiwa anak yang tersebar di ribuan pulau di Nusantara tersebut, jelas bahwa tanggung jawab perintah untuk melindungi anak-anak merupakan tugas raksasa yang sangat kompleks dan sulit. Peran pemerintah sangat diperlukan dalam pembuatan peraturan perundangundangan yang dapat menjaga penyelengaraan perlindungan anak. Namun dalam penyelengaraannya bukan hanya pemerintahan yang bertanggung jawab terhadap penyelengaraannya tetapi masyarakat turut membantu.

Fenomena-fenomena perilaku negative belakangan ini sangat sering kita jumpai dalam kehidupan sehari-hari, mulai dari kekerasan fisik, verbal, mental, bahkan pelecehan dan kekerasan seksual. Bentuk kekerasan seperti ini biasanya dilakukan oleh orang trdekat atau orang yang telah dikenal anak, seperti keluarga, ayah kandung, ayah tiri, paman, tetangga, guru maupun teman sepermainannya sendiri. Khasus anak-anak korban pelecehan seksual, biasanya belum mengerti dia sedang dilecehkan.

Masa usia dini sering di sebut masa keemasan (golden age) masa keemasan adalah masa dimana anak usia dini mampu menerima informasi dengan

\footnotetext{
${ }^{1}$ Undang-Undang Republik Indonesia Nomor 35 Tahun 2014 Tentang Perubahan Atas Undang-Undang Nomor 23 Tahun 2002 Tentang Perlindungan Anak.

${ }^{2}$ Jumlah penduduk Indonesia 2019, (on-line) (https://databoks.katadata.co.id) diakses pada tanggal 29 oktober 2019.
} 
sangat pesat. Montesori (Hainstock) mengatakan bahwa masa ini merupakan periode sensitif (sensitive perods), selama masa inilah anak usia dini dengan mudah menerima stimulus-stimulus dari lingkungannya. ${ }^{3}$ Pada masa keemasan ini. kemampuan otak anak dalam menerima semua pengetahuan dari lingkungan sekitarnya diikuti dengan rasa ingin tahu yang sangat tinggi. Rasa ingin tahu ini ditunjukan anak dengan aktif bertanya tentang berbagai hal yang mereka temui atau dapatkan. Hal ini sesuai dengan pendapat Montessori (sujiono) yang berpendapat bahwa "Anak usia dini senang sekali belajar'selalu ingin tahu dan mencoba". ${ }^{4}$ Rasa ingin tahu anak usia dini meliputi semua bidang yang menurut anak menarik atau menyenangkan, salah satunya yang berkaitan dengan seksualitas.

Perkembangan seksualitas pada anak usia dini sendiri dimulai dari usia tiga tahun, yaitu dari hal yang paling mendasar dimana anak sudah dapat membedakan jenis kelamin dan perbedaan fisik. Seiring dengan pertumbuhan anak. Anak akan mengalami mengelus diri sendiri, memanipulasi genetikal, memeluk boneka, hewan peliharaan, dan orang yang disayangi. Jika kita tidak memberikan pemahaman terhadap anak. Maka perkembangan seksualnya akan terganggu dan presepsi yang salah tentang jenis kelamin, proses reproduksi dan seksualitas. Akan berpengaruh terhadap anak dan dapat menyebabkan anak mengalami penyimpangan seksual pada saat dia dewasa.

Berikut adalah data KPAI dan LPSK berkaitan dengan kasus pelecehan seksual terhadap anak usia dini 2018-2019: Di tahun 2019 , hingga bulan oktober, Komisi Perlindungan Anak Indonesia (KPAI) menemukan masih banyaknya kasus kekerasan seksual terhadap anak dilingkungan sekolah, masalah itu pun masih berdasarkan pengawasan di media massa. Data KPAI menunjukan hingga oktober, kasus kekerasan seksual di dunia pendidikan mencapai 17 kasus dengan 89 anak menjadi korban, mereka terdiri dari 55 perempuan dan 34 laki-laki, sedangkan menurut lembaga perlindungan saksi dan korban (LPSK) mencatat ada peningkatan kasus kekerasan seksual pada anak yang terjadi sejak 2016 sejumlah 25 kasus, lalu meningkat pada tahun 2017 sejumlah 70 korban, dan sebanyak 149 korban pada 2018. Sampai dengan bulan juni 2019 telah mencapai 78 pemohonan terhadap kasus kekerasan seksual terhadap anak. $^{5}$

Menurut Khofifah Indar Parawansa dalam konferensi pers hasil Penelitian tentang kekerasan seksual Anak Terhadap Anak. Penelitian ini dilakukan oleh

\footnotetext{
${ }^{3}$ Hainstock, Elizabeth, Metode Pengajaran Montesori Untuk Anak Prasekolah. (Jakarta:Pustaka Delapratasa,1999), 10-11.

${ }^{4}$ Sujiono, Yuliana Nuraini, Konsep Dasar Pendidikan Anak Usia Dini, (Jakarta: Indeks, 2013), 107.

${ }^{5}$ Data Komisi Pelindungan Anak Indonesia (KPAI) dan Lembaga Perlindungan Saksi dan Korban (LPSK) 2019 (berita on-line) (https://m.detik.com) diakses pada tanggal 29 oktober 2019.
} 
Balai Besar Penelitian dan Pengembangan Pelayanan Kesejahteraan Sosial Yogyakarta (B2P3KS) bekerja sama dengan End Child Prostitution, Children For Sexual Purposes (ECPAT) Indonesia. Penelitian tersebut dilakukan di lima wilayah yakni Jakarta Timur, Magelang, Yogyakarta, Mataram dan Makassar dengan metode wawancara mendalam terhadap 49 anak yang melakukan kekerasan seksual terhadap anak, orang tua, guru, kepala panti, pekerja sosial, stakeholder. Dalam hasil penelitian tersebut juga menunjukkan pelaku kekerasan seluruhnya berjenis kelamin laki-laki dengan rata-rata usia 16 tahun. Kekerasan dilakukan oleh pelaku melalui paksaan $(67 \%)$ sementara itu bentuk kekerasan yang dilakukan berupa sentuhan/rabaan organ sensitive (30\%) hingga hubungan badan $(26 \%)$. Mayoritas pelaku masih tinggal dengan orang tua $(61,22 \%)$ tempat terjadi kekerasan seksual di antaranya di rumah teman $(30,56 \%)$ dan di rumah korban $(19,44 \%)$ mayoritas pelaku dan korban telah saling kenal $(87 \%)$. Korban kekerasan seksual anak terungkap bahwa rentang usia mereka adalah 5-17 tahun. Karakteristik korban sebanyak 35,44\% bersifat pendiam, cengeng dan pemalu. Sebanyak 24,05\% bersifat hiperaktif dan bandel dan sebanyak 13,92\% senang berpakaian minim. "sementara dari sisi karakteristik social ekonomi keluarga baik perilaku maupun korban menunjukkan bahwa 55\% merupakan keluarga yang didamping dua orang tua dan $45 \%$ merupakan keluarga cerai/meninggal," Yang paling mendominasi kejahatan seksual terhadap anak diantarnya adalah pornografi (43\%), pengaruh teman (33\%),pengaruh narkoba/obat (11\%).pengaruh histori pernah menjadi korban atau trauma masa keci (10\%) pengaruh keluarga $(10 \%){ }^{6}$

Ketidak pahaman anak terhadap pelecehan seksal sehingga anak hanya diam dan takut melaporkan kasus-kasus kekerasan seksual yang menimpanya. Oleh karena itu, pembicaraan, bimbingan dan arahan berkaitan dengan seks ternyata sangatlah penting untuk anak dalam perkembangan seksual anak. Dalam bidang pendidikan, sekolah dan guru memiliki peran penting untuk mencegah terjadinya kekerasan seksual terhadap anak dengan memperkenalkan pendidikan seks kepada anak usia dini, hal ini sangatlah penting mengingat kejahatan seksual makin marak dan korbannya di mulai dari anak-anak usia 3 tahun.

PAUD memiliki peran yang penting dalam memberikan layanan perlindungan, termaksut memperkenalkan pendidikan seks kepada anak usia dini. Hal ini sesuai dengan pasal 35 dari UU Nomor 137 Tahun 2014 tentang Standar Nasional Pendidikan Anak Usia Dini di bawah ini:

${ }^{6}$ Balai Besar Penelitian dan Perkembangan Pelayanan Kesejahteraan Sosial Yogyakarta (B2P3S) bekerja sama dengan End Child Prostitutation,Childeren For Sexual Purposes (ECPAT) (on-line) (https://Surabaya.co.id) diakses 29 oktober 2019. 
Pelaksanaan program PAUD merupakan intergrasi dari layanan pendidikan,pengasuhan, perlindungan, kesehatan, dan gizi yang di selengarakan dalam bentuk satuan program Taman Kanak-kanak (TK)/Raudatul Athfal (RA),Bustanul Atfal (BA), kelompok bermain (KB), Taman penitipan anak (TPA), dan satuan PAUD sejenis (SPS). ${ }^{7}$

Berdasarkan latar belakang di atas, penulis tertarik untuk meneliti penerapan pembelajaran pendidikan seksual untuk anak usia dini melalui media lagu di sekolah. dari hasil kunjungan terhadap beberapa sekolah di Kota Palu dan Kabupaten Sigi. Pada survei yang di lakukan penulis pada tanggal 20 Juli 2019, maka KB Siti Khadija Desa Pakuli Kecamatan Gumbasa Kabupaten Sigi penulis tertarik melakukan penelitian di tempat tersebut karena sekolahnya masih taraf kelompok bermain (KB) rata-rata umur anak 3-4 tahun yang masih dalam masa ke emasan (golden age) sehingga lebih mudah untuk menerapkan pedidikan seksual untuk anak usia dini karena masa ini anak dapat mengingat jangka panjang dan pada masa 3 tahun masa ini sangat penting dalam masa identifikasi alat kelamin pada anak.

\section{METODE PENELITIAN}

Jenis penelitian yang digunakan dalam penelitian ini adalah penelitian kualitatif. Lokasi penelitian yakni di Kelompok Bermain (KB) Siti Khadija Desa Pakuli Kecamatan Gumbasa Kabupaten Sigi.

Teknik pengumpulan data yang digunakan adalah teknik observasi, dokumentasi dan wawancara. Adapun teknik analisis data yang dilakukan meliputi reduksi data, penyajian data dan verifikasi data. Data-data yang telah didapatkan dari lokasi penelitian sangat penting untuk dicek kembali, agar benarbenar memperoleh data yang akurat sesuai harapan. Empat kriteria yang menunjukkan keabsahan suatu data, yang menurut Lexy J. Moelong adalah 'derajat kepercayaan (credibility), keteralihan (transferability), ketergantungan (dependability) dan kepastian (konfirmality). ${ }^{8}$ Selanjutnya, untuk mengecek keabsahan data yang diperoleh maka dilakukan tehnik pemeriksaan atau pengecekan data yang memanfaatkan sesuatu yang lain, diluar data itu untuk keperluan pengecekan dan perbandingan. Menurut sugiyono, Tiga macam triangulasi sebagai tehnik pemeriksaan yaitu "triangulasi dengan sumber, triangulasi dengan tehnik pengumpulan data, triangulasi waktu. ${ }^{9}$

\footnotetext{
${ }^{7}$ Undang-Undang Republik Indonesia Pasal 35 Nomor 137 Tahun 2014 Tentang Standar Nasional Pendidikan Anak Usia Dini.

${ }^{8}$ Lexy J. Moleong, Metodologi Penelitian Kualitatif (Bandung : Rosdakarya, 2010), 115

9 Sugiyono, Metode Penelitian Pendidikan Pendekatan Kuantitaf, Kualitatif Dan R\&D (Cet.XX;Bandung: Alfabet, 2014), 179.
} 


\section{HASIL DAN PEMBAHASAN}

\section{A. Pelaksanaan Pendidikan Seks pada Anak Usia 3-4 Tahun melalui Media Lagu KB Siti Khadija Desa Pakuli Kec. Gumbasa Kab. Sigi}

Pendidikan seksual merupakan kebutuhan yang sangat penting diketahui oleh anak usia dini sehingga anak dapat melindungi dirinya dari bahaya laten disekitarnya. Karna dengan banyaknya kasus-kasus kekerasan seksual sekarang ini maka dari itu edukasi pendidikan seks sangat penting karena dapat pencegahan (preventif) untuk dapat meminimalisir kekerasan seksual dimasa depan. Pendidikan seksual juga sudah diterapkan di Negara-negara maju maupun Negara berkembang lainnya di Indonesia sendiri edukasi pendidikan seks telah dimasukan dalam kurikulum 2013 dalam pembahasan reproduksi.

Pendidikan seks juga dapat dikombinasikan dengan pembelajaran dan tema yang menyenakan contohnya seperti lagu sentuhan boleh dan sentuhan tidak boleh. Anak dilatih mengenali dirinya sendiri sehingga dia merasa bahwa dirinya berharga, pendidikan seksual sendiri dapat merangsang kognitif, sosial, motorik halus dan motorik kasar. Dalam hal pendidikan seksual guru dituntut dapat sekreatif mungkin agar enam aspek perkembangan dapat berkembang dengan sesuai harapan. Semakin banyak keterlibatan perkembangan enam aspek tersebut dalam pembelajaran seks maka semakin baik untuk anak karena tidak hanya mendapatkan edukasi yang bermanfaat tetapi perkembangan anak juga dapat berkembang dengan demikian sekolah harus memberikan pemahaman tentang pendidikan seks dan tujuan yang kuat.

Tujuan sekolah kami memberikan pendidikan seks yaitu memberikan informasi yang benar kepada anak tentang kesehtan reproduksi agar anak-anak mengerti tentang kesehatan reproduksi sehingga tindakan pelecehan seks dapat diminimalisir. ${ }^{10}$

Tujuan utama pendidikan seks yaitu memberikan pemahaman terhadap anak tentang angota tubuh fungsinya serta kesehatan reproduksi agar anak lebih mengenali dirinya dan lebih menghargai dirinya sendiri agar terhindar dari bahaya predator seks di sekitarannya.

Pendidikan seksual sebaiknya diterapkan sejak dini karna usia anak 3 tahun adalah masa golden age anak artinya apa pun yang kita ajarkan sejak dini dapat anak ingat sampai ketika dia dewasa sedangkan di KB Siti Khadija sendiri awalnya diterapkan sekitar 3 tahun yang lalu kami mulai memberikan

${ }^{10}$ Hertin Lamasaido, Kepala Sekolah Di KB Siti Khadija Desa Pakuli Kec. Gumbasa Kab. Sigi "Wawancara" di ruang Kepala Sekolah,Tanggal 2 juli 2020. 
pemahaman pendidikan seksual tentunya sudah ada persetujuan dari orang tua murid karena sebelum kita menerapkan pendidika seksual terhadap anak kami melakukan sosialisasi dengan orang tua murid selanjutnya pendidikan seksual kami ajarkan kepada anak secara detail pada saat tema diriku dan kami melakukan edukasi pendidikan seksual melalui media lagu sentuhan boleh sentuhan tidak boleh itu salah satu lagu wajib yang di nyanyikan setiap hari selama masa pembelajaran oleh peserta didik di KB Siti Khadija Desa Pakuli, lagu ini dinyanyikan selepas istirahat makan menjelang anak pulang. ${ }^{11}$

Pendidikan seks dapat diajarkan sejak dini ketika anak telah memahami perkataan karena pada usia 3-4 tahun anak dalam masa golden age pada masa ini anak dapat mengingat jangka panjang hinga anak dewasa bahwa masa ini sangat penting untuk perkembangan identifikasi jenis kelamin pada anak, bagaimana seharusnya anak laki-laki atau anak perempuan bersikap, berpakain, dan berperan. Jika pada masa ini lingkungan tidak mendukung anak untuk mengidentifikasi dirinya dengan baik, maka anak akan mengalami bias atau ketidak jelasan dalam mengidentifikasi dirinya sebagai seorang laki-laki atau perempuan. Peran guru dalam memberikan pembelajaran seksual sangat dibutuhkan dan sekolah berperan aktif dalam menyusun perencanaan pembelajaran seks.

Pendidikan seksual bertujuan memberikan pemahaman terhadap anak tetang angota tubuh fungsinya serta kesehatan reproduksi agar anak lebih mengenali dirinya dan lebih menghargai dirinya sendiri dan pendidikan seksual baik di ajarkan ketika umur 3-6 tahun karna masa ini masa golden age dan masa mengidentifikasi pada anak materi yang diajarkan harus menarik dan sesuai dengan perkembangan dari peserta didik pembelajaran seks juga harus diterapkan setiap hari agar anak lebih paham tentang pendidikan seks dapat dikolaborasi dengan berbagai tema agar anak tidak mudah bosan dan jenuh di dalam kelas, karena dengan menariknya alat peraga meskipun alat peraganya kurang memadai yang paling penting guru menyiapkan sekreatif mungkin, supaya anak-anak yang di dalam kelas tidak mudah bosan dalam pembelajarannya, dengan adanya media dan alat peraga anak-anak semangat untuk belajar. Pada saat melakukan proses pembelajaran guru selalu menggunakan RPPH sebagai pedoman dalam melaksanakan proses pembelajaran di Kelompok bermain siti khadija desa pakuli. Tanpa komponen tersebut pembelajaran dikatakan tidak memenuhi syarat dalam sistem penilaian perkembangan anak dalam proses belajarnya. Sehingga pentingnya RPPH

\footnotetext{
${ }^{11}$ Ika Juniarti guru kelas di KB Siti Khadija Desa Pakuli Kec. Gumbasa Kab. Sigi "Wawancara" di ruangan guru, Tanggal 6 juli 2020.
} 
dalam mengajarkan untuk anak yang dimiliki setiap guru yang akan melakukan proses pembelajarannya.

\section{B. Keberhasilan Pendidikan Seks Melalui Media Lagu di KB Siti Khadija Desa Pakuli Kec. Gumbasa Kab. Sigi}

Keberhasilan pendidikan seks di sekolah tidak terlepas dari peran setiap guru karna pada dasarnya pemberian pendidikan seks tergantug seberapa kopentenya guru dalam memberikan pendidikan seks tersebut pembelajaran- pembelajaran yang berfariatif akan membawa anak dalam pengalaman belajar yang menyenangkan sehingga proses pembelajar akan berjalan dengan baik pendidikan seks dapat dikatakana berhasil apabila pendidik mampu membimbing peserta didik untuk menjadi pribadi yang lebih baik, pendidik juga mempunyai peran yang sangat penting dalam penerapan edukasi pendidikan seks karna pendidikan ini berkaitan dengan kehidupan khususnya manusia, sehingga sulit dipisahkan dari kehidupan, sifatnya mutlak dalam kehidupan, baik dalam kehidupan anak, keluar, dan lingkungan sekitar, bangsa, dan Negara. Berkembangnya suatu bangsa banyak ditentukan oleh majunya pendidikan bangsa itu sendiri. dalam mencapai keberhasilan dalam mengajarkan pendidikan seksual guru harus mempunyai wawasan yang luas tentang pendidikan seks tentunya itu sangat penting karna ketika guru tidak memahami tentang pendidikan seks maka pembelajaran tidak berguna untuk peserta didik.

Dikelompok bermain Siti Khadija sendiri kepala sekolah dan setiap guru disini tentunya belum pernah ikut seminar pendidikan seks yang diadakan oleh pemerintah Sigi, mungkin ada tetapi pihak sekolah sendiri belum mendengar tentang seminar pendidikan seks yang dipelopori pemerintah Kabupaten Sigi untuk memberikan informasi berkaitan dengan pendidikan seks tetapi sekitar 3 tahun yang lalu guru-guru disini mengadakan sosialisasi kecil-kecilan tentang pentingnya pendidikan seks untuk diajarkan ke peserta didik ditambah dengan mahasiswa dari kampus Institut Agama Islam (IAIN) Palu kebetulan mahasiswa sekitar 6 orang berkunjung ke sekolah kami dan guru-guru disini mengajak mahasiswa untuk mendiskusikan tentang pentingnya pendidikan seks untuk anak materinya sendiri diambil lewat sosial media yotube, dan guru-guru serta mahasiswa mendiskusikan apa yang mereka lihat melalui youtube. ${ }^{12}$

Kurangnya sosialisasi tentang pendidikan seks disatuan PAUD membuat pendikan ini masih diangap tabu dikalangan masyarakat padahal edukasi pendidikan seks ini sangat penting diajarkan kepada anak, di KB Siti Khadija sendiri berinisiatif untuk melakukan pendidikan seks tentunya sudah mendapatkan persetujuan dari

${ }^{12}$ Hertin Lamasaido. Kepala Sekolah Di KB Siti Khadija Desa Pakuli Kec. Gumbasa Kab. Sigi "Wawancara" di ruang kepala sekola,Tanggal 9 juli 2020. 
orang tua murid karna sekolah sendiri adalah lembaga yang paling terpercaya dan netral dimana edukasi seksual dibahas arti sesunguhnya dari seks yaitu perbedaan jenis kelamin yang dapat dilihat antara perempuan dan laki-laki agar lebih efektif dalam pemberian pembelajaran seksual maka media-media pembelajaran harus memadai.

Menurut pengamatan kami lagu sentuhan boleh dan sentuhan tidak boleh sangat efektif dalam pembelajaran seks disamping baitnya mudah dihafal dalam liriknya juga penuh makna yang dalam lagu ini juga mengajarkan tentang bagian tubuh dan pada saat kami mengajarkan anak tentang lagu tersebut kami menciptakan gerakan-gerakan sederhana agar 6 aspek perkembangan seperti kognitif, motorik halus, motorik kasar, sosial emosional, bahasa dan seni dapat berkembang sesuai harapan contohnya seperti kognitif dia dapat mengingat setiap bait dari lagu sentuhan boleh dan sentuhan tidak boleh, motorik halus dia dapat mengerakan jari tangan dan menyentuh bagian tubuh lainya, motorik kasar anak dapat mengerakan kakinya untuk bergoyang, sosial emosionalnya anak-anak dapat bernyanyi bersama teman-temannya, bahasa anak dapat mengucapkan kata yang ada di setiap bait lagu sentuhan boleh dan sentuhan tidak boleh, dan seni anak dapat menyanyi. Jadi selain mendapatkan pemahaman tenang pendidikan seks anak dapat mengembangkan 6 aspek perkembangan. ${ }^{13}$

Pembelajaran yang efektif ketika media pembelajaran cukup bervariatif tetapi di KB Siti Khadija masih kurangnya media pembelajaran sehingga guru-guru berinovasi menggunakan apa yang ada untuk pembelajaran seks salah satunya dengan mengunakan media lagu sentuhan boleh dan sentuhan tidak boleh dalam pembelajaran seks sudah cukup efekti karna anak-anak tidak hanya mendapatkan tentang pendidikan seksual tetapi 6 aspek perkembangan juga dapat berkembang sesuai harapan dan keaktifan guru agar peserta didik mau mengikuti pembelajaran.

Dalam pembelajaran yang efektif agar anak mengikuti tentang pembelajaran guru harus berperan aktif dalam pembelajaran salah satunya edukasi pendidikan seks guru-guru juga tidak bisa memaksakan anak-anak untuk ikut pembelajaran seks karna anak usia dini itu tugasnya bermain sambil beljar jadi pembelajaran di kemas sedemikian rupa agar anak mau mengikuti pembelajaran dan pertanyaan-pertanyaan dari anak sebisa mungkin guru menjawab dengan sederhana agar anak mudah paham sehingga pembeljaran berjalan dengan baik.

Pendidikan seks dapat berhasil ketika guru-guru dapat memahami tentang pendidikan seks, dalam memahami pendidikan seks guru tentunya perlu mendapatkan sosialisasi atau pemahaman tentang pendidikan seks dari pemerintah karna pendidikan seks ini sangat penting dan dalam menunjang keberhasilan pendidikan

${ }^{13}$ Elsa, Guru kelas di KB Siti Khadija Desa Pakuli Kec. Gumbasa Kab. Sigi "Wawancara" di ruang guru,Tanggal 9 juli 2020 
seks juga sekolah perlu mengunakan media yang memadai, di KB Siti Khadija sendiri masih kurangnya media yang berbentuk poster tentang angota tubuh maka guru-guru di KB Siti Khadija memanfaatkan media yang ada yaitu video maupun lagu-lagu yang berkaitan dengan pendidikan seks, salah satu lagu yang sudah menjadi lagu wajib di KB Siti Khadija yaitu lagu sentuhan boleh dan sentuhan tidak boleh lagu ini sangat baik dalam mengajarkan edukasi pendidikan seksual karna tidak hanya pembahasan tentang pendidikan seks lagu ini juga membahas tentang angota tubuh serta lagu ini dapat dikombinasikan dengan 6 aspek perkembangan melalui gerakan dalam melatih pembentukan motorik halus dan motorik kasar anakanak sangat tertarik dalam pembelajaran seks karna anak-anak dapat menanyi dan bermain game tentang pendidikan seks keberhasilan ini tentunya tidak luput peran guru dalam membuat pembelajaran yang kreatif, respon anak dalam menerima pendidikan seks sendiri aktif dan sangat antusias sama seperti dalam menerima pendidikan lainya tetapi yang membedakan disini anak lebih banyak bertanya tentang pertanyaan yang berkaitan dengan pendidikan seks dan guru-guru harus menjawab sesederhan mungkin agar dapat di pahami anak kendala dalam pembelajaran seks sendiri masi banyak anak yang tidak patuh, masi ada anak-anak bosan dalam menanyikan lagu sentuhan boleh dan sentuhan tidak boleh dan masih kurangnya media pembelajaran dalam menunjang pendidikan seks.

\section{KESIMPULAN}

Berdasarkan hasil pembahasan dalam penelitian ini, maka penulis dapat mengemukakan beberapa kesimpulan sebagai berikut:

1. Pelaksanaan pendidikan seks di lakukan dengan mengajarkan anak pendidikan seksual sesuai pada anak berusia 3-4 tahun, Sekolah telah merancang pendidikan seksual yang efektif dalam pemberian pembelajaran ke peserta didik, mengunakan metode bercerita dan Tanya jawab antara guru dan siswa serta mengunakan media lagu sekolah juga mengunakan tema diriku dalam pembahsan full tentang pendidikan seks.

2. Keberhasilan pendidikan seks di KB siti khadija sendiri terlihat ketika sekola berinisiatif membuat diskusi bersama guru-guru untuk membahas tentang pentingnya pembelajaran seks, dan pengunaan media lagu sentuhan boleh dan sentuhan tidak boleh sebagai lagu wajib dinyanyikan peserta didik sebelum pulang sekolah, pengunaan lagu juga dikombinasikan dengan 6 aspek perkembangan yaitu, nilai agama dan moral, bahasa, kognitif, motorik kasar dan halus, sosial-emosional, dan seni. 


\section{SARAN}

Sebagai tindak lanjut penelitian yang Penulis lakukan maka ada beberapa saran sebagai berikut:

1. Pendidikan seks sangat penting diajarkan kepada anak usia dini karna dengan banyaknya kasus-kasus kekerasan diseluru Indonesia dan sasarnya adalah anak yang belum mengerti bahwa mereka telah dilecehkan dengan kurangnya sosialisasi untuk orang tua dan sekolah menambah parah pengetahuan tentang seksual maka saat ini dimasyarakat masi mengangap pendidikan seks sangat di angap tabu. Oleh karena itu, pemerintah seharusnya lebih mengoptimalkan sosialisasi tentang edukasi pendidikan seks disetiap sekolah sehingga Taman Kanak-kanak wajib memberikan edukasi pembelajara seks karan sekolah adalah bagian terpenting dalam pembentukan karakter dan pengembangan 6 aspek. Terlebih lagi satuan PAUD yaitu jenjang pertama sekolah formal yang di tempu setiap anak di indonesia demi mendapatkan generasi baik penerus bangsa.

2. Untuk sekolah agar selalu memberikan hal-hal kreatif dalam mengenalkan edukasi pendidikan seks dan pemberian sosialisasi ke orang tua lebih dioptimalkan dan penambahan media-media pembelajaran berkaitan dengan edukasi pendidikan seks serta pemasangan poster di sekolah merupakan upaya untuk mengingatkan anak dan orang tua guru bahwa pendidikan seks sangat penting.

3. Untuk guru kelas maupun guru pendamping agar mempertahankan apa yang sudah dilakukan dan berusaha mengurangi kekurangan yang terjadi saat proses pembelajaran. Selain itu, dengan memperluas wawasan dalam hal pembuatan media dan alat permainan edukatif sesuai dengan perkembangan zaman sekarang, agar dalam proses pembelajaran anak tidak merasa jenuh dan dapat sesuai dengan kebutuhan aspek perkembangan anak.

\section{DAFTAR PUSTAKA}

Balai Besar Penelitian dan Perkembangan Pelayanan Kesejahteraan Sosial Yogyakarta (B2P3S) bekerja sama dengan End Child Prostitutation,Childeren For Sexual Purposes (ECPAT) (on-line) (https://Surabaya.co.id) diakses 29 oktober 2019.

Data Komisi Pelindungan Anak Indonesia (KPAI) dan Lembaga Perlindungan Saksi dan Korban (LPSK) 2019 (berita on-line) (https://m.detik.com) diakses pada tanggal 29 oktober 2019. 
Hainstock, Elizabeth, Metode Pengajaran Montesori Untuk Anak Prasekolah. Jakarta:Pustaka Delapratasa,1999.

Jumlah penduduk Indonesia 2019, (on-line) (https://databoks.katadata.co.id) diakses pada tanggal 29 oktober 2019.

Moleong, Lexy J. Metodologi Penelitian Kualitatif. Bandung : Rosdakarya, 2010.

Sugiyono, Metode Penelitian Pendidikan Pendekatan Kuantitaf, Kualitatif Dan $R \& D$ Cet.XX;Bandung: Alfabet, 2014.

Sujiono, Yuliana Nuraini, Konsep Dasar Pendidikan Anak Usia Dini, Jakarta: Indeks, 2013.

Undang-Undang Republik Indonesia Nomor 35 Tahun 2014 Tentang Perubahan Atas Undang-Undang Nomor 23 Tahun 2002 Tentang Perlindungan Anak.

Undang-Undang Republik Indonesia Pasal 35 Nomor 137 Tahun 2014 Tentang Standar Nasional Pendidikan Anak Usia Dini. 